\title{
Resiquimod and polyinosinic-polycytidylic acid formulation with aluminum hydroxide as an adjuvant for foot-and-mouth disease vaccine
}

\author{
Chun-Xue Zhou, Dong Li, Ying-Li Chen, Zeng-Jun Lu, Pu Sun, Yi-Mei Cao, Hui-Fang Bao, Yuan-Fang Fu, \\ Ping-Hua Li, Xing-Wen Bai, Bao-Xia Xie and Zai-Xin Liu*
}

\begin{abstract}
Background: Toll-like receptor (TLR) agonists reportedly have potent antiviral and antitumor activities and may be a new kind of adjuvant for enhancing immune efficacy. Resiquimod (R848) is an imidazoquinoline compound with potent antiviral activity and functions through the TLR7/TLR8 MyD88-dependent signaling pathway. Polyinosinic-polycytidylic acid [poly(l:C)] is a synthetic analog of double-stranded RNA that induces the production of pro-inflammatory cytokines by the activation of NF-KB through TLR3. This study investigated the potential of R848 and poly(l:C) as an adjuvant 146S foot-and-mouth disease virus (FMDV) vaccine formulated with aluminum hydroxide $\left(\mathrm{Al}(\mathrm{OH})_{3}\right)$.

Results: Antibody titers to FMDV and $\mathrm{CD}^{+} \mathrm{T}$ cells were markedly enhanced in mice immunized to $146 \mathrm{~S} F M D V+\mathrm{Al}(\mathrm{OH})_{3}+\mathrm{R} 848$ + poly $(\mathrm{l}: \mathrm{C})$ compared with mice immunized to FMDV + ISA206. IFN- $\gamma$ secretion substantially increased compared with IL-4 secretion by splenic T cells stimulated with FMDV antigens in vitro, suggesting that $\mathrm{R} 848$, poly $(\mathrm{l}: \mathrm{C})$, and with $\mathrm{Al}(\mathrm{OH})_{3}$ together biased the immune response toward a Th1-type direction.

Conclusions: These results indicated that the R848 and poly(l:C) together with $\mathrm{Al}(\mathrm{OH})_{3}$ enhanced humoral and cellular immune responses to immunization with 146S FMDV antigens. Thus, this new vaccine formulation can be used for FMDV prevention.
\end{abstract}

Keywords: R848, Poly(l:C), Aluminum hydroxide, FMDV

\section{Background}

Foot-and-mouth disease virus (FMDV), which belongs to family Picornaviridae, genus Aphthovirus, causes a highly contagious and devastating disease in cloven-hoofed animals, such as cattle, swine, sheep, and goats [1]. FMDV was first discovered by Loeffler and Frosch in the late nineteenth century [2]. Since then, outbreaks of foot-andmouth disease (FMD) in Asia and Europe have led to the slaughter of millions of infected animals and billions of dollar loss [3,4].

FMD, which has been reported in many areas of the world, has the features of fever, short-lived viremia, and lesions on feet and tongue. The disease can be controlled by

\footnotetext{
* Correspondence: lidong@caas.cn; liuzaixin@caas.cn

State Key Laboratory of Veterinary Etiological Biology, Key Laboratory of Animal Virology of Ministry of Agriculture, OIE/National Foot-and-Mouth Disease Laboratory, Lanzhou Veterinary Research Institute, Chinese Academy of Agricultural Sciences, Lanzhou 730046, China
}

vaccination of chemically inactivated whole virus formulated with adjuvant. Aluminum salts are the only ones licensed in human vaccines and mainly enhances Th2specific immune responses. Extensive clinical data have demonstrated that aluminum salt vaccines have excellent safety profiles and limited adverse reactions in injection sites. Both aluminum hydroxide $\left(\mathrm{Al}(\mathrm{OH})_{3}\right)$ adjuvant and mineral oil adjuvant have been applied to control FMD. However, the antibody titers were higher and the morbidity rates were lower in cattle, sheep, and pigs when emulsified oil is used as an adjuvant [5]. Moreover, the ability of the aluminum adjuvant to enhance Th1 cell-mediate immune responses is insufficient. However, mineral oil adjuvant can induce local and general reactions, such as granuloma, gangrene, or fever [6].

Toll-like receptors (TLRs) are pattern recognition receptors that play an important role in innate immune response.

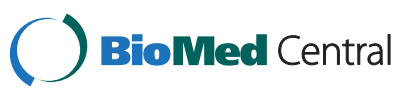


TLRs are preferentially expressed in lymphocytes, dendritic cells (DCs), and macrophages [7]. The engagement of TLRs in DCs links innate immunity and adaptive immunity, which is vital for immune cell maturation, cell differentiation (Th1/Th2) based on pro-inflammatory cytokines, and proliferation of antigen-specific $\mathrm{CD}_{4}^{+}$and $\mathrm{CD} 8^{+} \mathrm{T}$ cells [8]. To date, 13 TLRs have been confirmed in both humans and mice. Many natural or synthetic ligands that recognize the TLRs have also been discovered [9]. TLR7, which favors a TH1 response, can be activated by some synthetic agonists, such as imiquimod [10,11], resiquimod (R848) $[12,13]$, and 3 M-052 [14]. Imiquimod and R848 have been demonstrated to have immune response properties in terms of antiviral and antitumor activities. Imiquimod, the first synthetic imidazoquinoline, is approved for the topical treatment of genital warts, skin cancer, superficial basal cell carcinoma, and actinic keratosis [15]. Through conventional subcutaneous and intramuscular vaccination, R848 shows that these molecules could enhance DCs maturation, as well as cellular and humoral adaptive immunities in mice, rats, guinea pigs, and monkeys [16].

Polvriboinsine-polyribocyaidylic acid [poly(I:C)] is a synthetic analog of double-stranded RNA that could recognize TLR3 and lead to the activation of NF- $\mathrm{KB}$ and the secretion of pro-inflammatory cytokines. Poly(I:C) has been shown to induce the production of IL-12 and IFN- $\gamma$, which could shift the Th2-type response to Th1type response.

Thus far, ISA206 is considered the most effective oil adjuvant in FMD vaccines for protecting animals against infection. To determine if other types of adjuvants are more effective than ISA206, this study was carried out to determine the ability of $\mathrm{R} 848$ and poly(I:C) in assisting $\mathrm{Al}(\mathrm{OH})_{3}$ as $\mathrm{FMD}$ vaccine.

\section{Methods}

\section{Reagents and virus}

R848 and poly(I:C) were manufactured by SigmaAldrich (St. Louis, MO, USA). ISA206 was purchased from Seppic Company (France). $\mathrm{Al}(\mathrm{OH})_{3}$ (pH 7.4) was prepared in our laboratory and stored at $4^{\circ} \mathrm{C}$.

The FMDV strain used was a type-O FMDV vaccine strain isolated and stored in our laboratory. The procedures for virus preparation were performed as previously described [17]. This strain was propagated in a BHK-21 cell line and inactivated using binary ethyleneimine for $24 \mathrm{~h}$ at $37^{\circ} \mathrm{C}$. Then, $146 \mathrm{~S}$ antigen was concentrated and purified by sucrose density gradient centrifugation. In a typical procedure, appropriately inactivated virus samples were centrifuged through a cushion of $20 \%$ sucrose in TNE buffer [containing $10 \mathrm{mM}$ Tris- $\mathrm{HCl}(\mathrm{pH} 7.5), 0.1 \mathrm{M} \mathrm{NaCl}$, and $1 \mathrm{mM}$ EDTA] in an AH-625 rotor (Sorvall) at $25000 \mathrm{rpm}$, $2.5 \mathrm{~h}$, and $4^{\circ} \mathrm{C}$. The viral pellet was resuspended in TNE and centrifuged in $25 \%-45 \%(\mathrm{w} / \mathrm{w})$ sucrose density gradients in the same buffer at $37000 \mathrm{rpm}, 1 \mathrm{~h}$, and $4^{\circ} \mathrm{C}$ in a SW40 rotor (Beckman). After centrifugation, the gradients were scanned at $254 \mathrm{~nm}$ using UA-5 or UA-6 absorbance detectors. To prepare the whole virus particle standard, sucrose was removed by ultrafiltration using Centricon Plus-70 filter devices with Amicon Ultracel PL-30 membranes (Millipore, USA) following instructions from the manufacturer.

\section{Animals}

Female BALB/c mice (purchased from Lanzhou University, China), approximately 5 weeks to 8 weeks old, were used in this study. They were acclimated for a week before studies begun, i.e., maintained in standard mouse chow and conditions in an animal facility. All mice were weighed prior to initiation to provide a baseline for detecting the systemic toxicity of treatments that could cause weight loss. The State Key Laboratory of Veterinary Etiological Biology and Key Laboratory of Animal Virology of the Ministry of Agriculture approved all protocols using animals (permission number: CNAS-BL0012.date:2011.11-2016.11).

\section{Immunization protocols}

Mice in six groups (twelve mice each) were intramuscularly (IM) injected once in posterior limbs with one of the following formulations: (1) $146 \mathrm{~S}+\mathrm{ISA} 206(\mathrm{~F}+206)$, (2) $146 \mathrm{~S}+\mathrm{Al}(\mathrm{OH})_{3} \quad(\mathrm{~F}+\mathrm{A}), \quad(3) \quad 146 \mathrm{~S}+\mathrm{Al}(\mathrm{OH})_{3}+20 \quad \mu \mathrm{g}$ poly $(\mathrm{I}: \mathrm{C})(\mathrm{F}+\mathrm{A}+\mathrm{P}), \quad$ (4) $146 \mathrm{~S}+\mathrm{Al}(\mathrm{OH})_{3}+20 \mu \mathrm{g} 848$ $(\mathrm{F}+\mathrm{A}+\mathrm{R}), \quad(5) \quad 146 \mathrm{~S}+\mathrm{Al}(\mathrm{OH})_{3}+20 \quad \mu \mathrm{g} \quad \operatorname{poly}(\mathrm{I}: \mathrm{C})+$ $20 \mu \mathrm{g} R 848(\mathrm{~F}+\mathrm{A}+\mathrm{P}+\mathrm{R})$, and (6) placebo (PBS). 146S FMDV was administrated at $2.0 \mu \mathrm{g}$ per mouse. All tested mice were bled before immunization (day 0) and then immunized. Blood samples were obtained at 3, 7, 14, 21,28 , and 35 days post-vaccination (dpv). Sera were separated by centrifugation at $4000 \mathrm{rpm}$ for $10 \mathrm{~min}$ and stored at $-20^{\circ} \mathrm{C}$ until antibody titers were tested.

\section{Determination of FMDV type $\mathrm{O}$ specific antibody titers}

To measure FMDV type O-specific antibody titers following immunization, blood was obtained from each mouse. ELISA was performed according to the specifications in an LPB-ELISA commercial kit (LVRI, China). In a typical procedure, the ELISA plates were coated with rabbit antiserum against FMDV type $\mathrm{O}$ overnight at room temperature. Serum sample dilutions (from 1:4 to 1:512) were incubated overnight at $4^{\circ} \mathrm{C}$ at a pre-titrated dose of the corresponding virus strain (FMDV O type in this study) in a saline buffer liquid phase. The next day, the mixtures in the serum dilution plate were transferred into the ELISA plate and incubated for $1 \mathrm{~h}$ at $37^{\circ} \mathrm{C}$. After a washing step (total of five times with PBST), a second incubation was carried out with guinea pig antiserum against FMDV $\mathrm{O}$ type for $1 \mathrm{~h}$ at $37^{\circ} \mathrm{C}$. After a wash step similar to the one above, $50 \mu \mathrm{L}$ of prepared rabbit anti- 
Guinea IgG/HRP was added to each well. Well were then covered with a plate sealer and incubated for $1 \mathrm{~h}$ at $37^{\circ} \mathrm{C}$. Then, $50 \mu \mathrm{L}$ of the substrate/chromophore mixture $\left(\mathrm{H}_{2} \mathrm{O}_{2} / \mathrm{OPD}\right)$ was added to each well, and the plate (without plate sealer) was incubated for $15 \mathrm{~min}$ at room temperature in the dark. Finally, $50 \mu \mathrm{L}$ of stop solution was added to each well, and absorbance at $492 \mathrm{~nm}$ was read within 15 min of stopping the reaction.

\section{Preparation of splenic lymphocytes}

Individual spleens were cut into small pieces with scissors. Single cell suspension was prepared by gently squeezing through a $70 \mu \mathrm{m}$ cell strainer. Leukocytes were isolated by density gradient centrifugation for $20 \mathrm{~min}$ at $1000 \times g$ using Ez-Sep Mouse $1 \times$ lymphocyte separation medium (Dakewe, China). The portion of the medium containing lymphocyte was transferred into a new tube and then washed with RPMI 1640. Cells were isolated by density gradient centrifugation for $10 \mathrm{~min}$ at $450 \times g$, and the supernatant was discarded. Finally, cells were resuspended in RPMI 1640 (containing penicillin/ streptomycin) supplemented with 5\% FCS at $5 \times 10^{6}$ cells $/ \mathrm{mL}$ and stored at $4^{\circ} \mathrm{C}$.

\section{Detection of IFN- $\gamma / \mathrm{IL}-4$}

About $5 \times 10^{5}$ spleen lymphocytes were added to each well of a 96-well microtiter plate at a final volume of $100 \mu \mathrm{L}$. Cells from each spleen or pools of spleens were added to each of 9 wells, 3 for PBS control, 3 for PHA control $(10 \mu \mathrm{g} / \mathrm{mL}$; Sigma), and $3 \mathrm{for} 2 \mu \mathrm{g} / \mathrm{ml}$ of specific antigen (146S FMDV) challenge. The cells were then incubated for $48 \mathrm{~h}$ at $37^{\circ} \mathrm{C}$ in a humidified atmosphere of $5.0 \% \mathrm{CO}_{2}$ in air. The plates were then centrifuged for $10 \mathrm{~min}$ at $4000 \mathrm{rpm}$ to settle cells to the well bottom, and the medium was removed for analysis of IFN- $\gamma$ and IL-4 production by ELISA (BD Company, USA).

\section{Detection of $\mathrm{CD}^{+}{ }^{+} \mathrm{CD}^{+} \mathrm{T}$ and $\mathrm{CD}^{+}{ }^{+} \mathrm{CD} 8^{+} \mathrm{T}$ cells}

For $\mathrm{CD}^{+} \mathrm{CD}^{+}$and $\mathrm{CD}^{+} \mathrm{CD}^{+} \mathrm{T}$ cell staining, total spleen lymphocytes from immunized mice were isolated and stained with anti-CD3-ALEXA FLUOR ${ }^{\circ} 88$ \& anti-CD4ALEXA FLUOR ${ }^{\circ} 647$ or anti-CD3-ALEXA FLUOR ${ }^{\circ} 488$ \& anti-CD8-ALEXA FLUOR ${ }^{\circ}$ 647(BD Phamingen, USA) in darkness for $20 \mathrm{~min}$. Cells were isolated by density gradient centrifugation for $10 \mathrm{~min}$ at $3000 \mathrm{rpm}$. After discarding the supernatant, cells were twice washed with PBS and resuspended in $0.5 \mathrm{~mL}$ of PBS. The cells were then analyzed with a FACSAria (BD) within $4 \mathrm{~h}$.

\section{Statistical analyses}

The statistical significance of the differences in the means of experimental groups was determined by one- or twoway ANOVA analysis. Results are expressed as the mean \pm standard error of mean. A difference was deemed statistically significant if $p<0.05$.

\section{Results}

Effects of R848 and poly(I:C) on naïve splenocytes in vitro Naïve BALB/c splenocytes were prepared and stimulated with either R848 $(0.01,0.1,1,10,20,40,100 \mu \mathrm{g} / \mathrm{mL})$ or poly(I:C) $(0.01,0.1,1,10,20,40$, and $100 \mu \mathrm{g} / \mathrm{mL})$. ConA (Sigma Chemical Company, USA) were used as positive control, and PBS was used as negative control (Figure 1). Splenocytes were cultured for $48 \mathrm{~h}$, and cytokine induction was measured by harvesting splenocyte supernatants. To investigate the effect of R848 and poly(I:C) on the changes in Th1 and Th2 immune response in vitro, splenocyte supernatants were measured with a commercially available kit (BD company, USA). When tested for

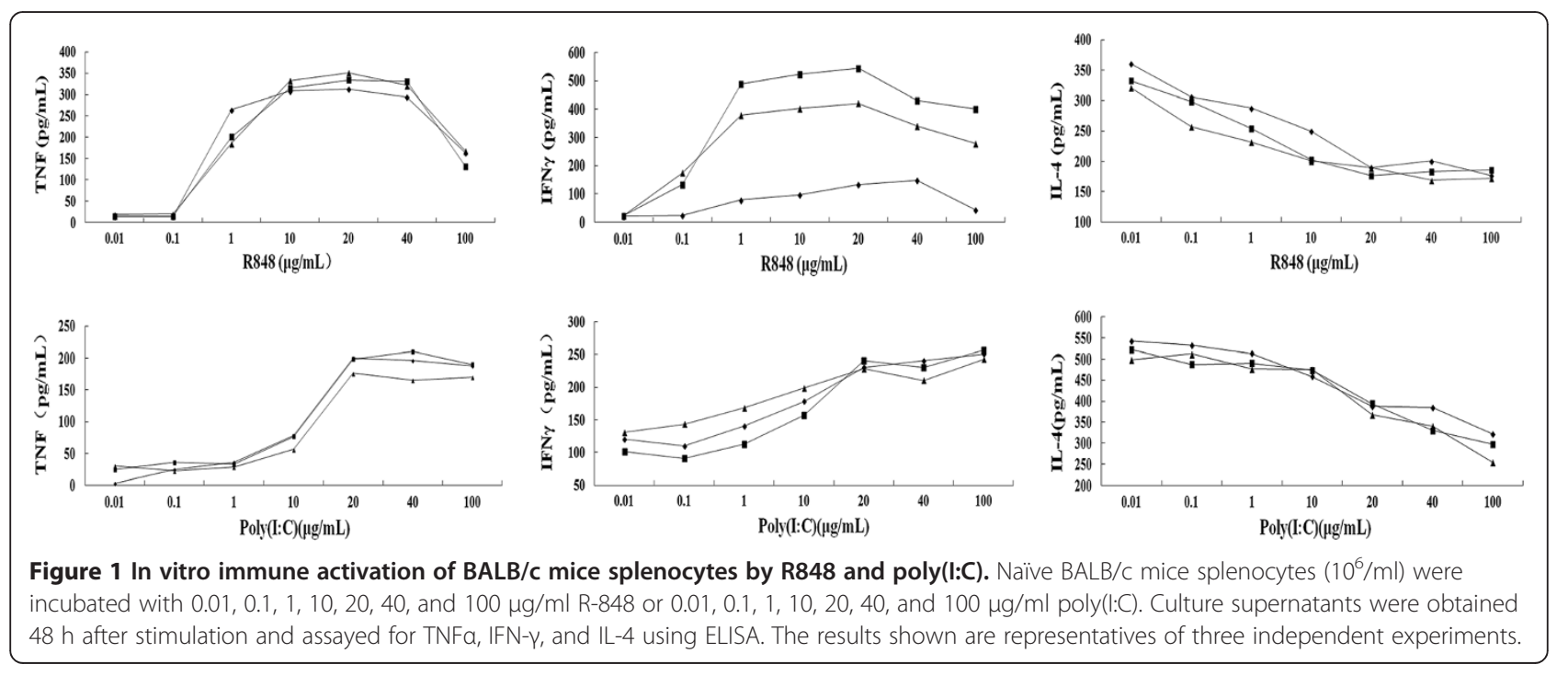


the ability to promote the induction of several different cytokines, both $\mathrm{R} 848$ and poly $(\mathrm{I}: \mathrm{C})$ induced the highest levels of TNF and IFN $\gamma$ (Th1 cytokine) at $20 \mu \mathrm{g} / \mathrm{mL}$. R848 appeared to be superior to poly(I:C) in inducing TNF and IFN $\gamma$. However, R848 and poly(I:C) induced the lowest levels of IL-4 (Th2 cytokine) when they were administered at $20 \mu \mathrm{g} / \mathrm{mL}$. Results revealed that both $\mathrm{R} 848$ and poly(I:C) regulated the production of selective Th1 or Th2 cytokines, which favor a Th1 bias [18].

\section{Antibody response}

Humoral immune responses were analyzed by screening for serum IgG using liquid-blocking ELISA specific for FMDV type O. Sera were collected prior to immunization and at different days after the immunization. The levels of anti-FMDV type $\mathrm{O}$ IgG at different days following immunization to FMDV formulated with different materials are shown in Figure 2. Pre-immune sera (day 0) were detected and found negative for anti-FMDV antibodies. Immunization to FMDV formulated with alum and R848 induced a weaker IgG antibody response than the $\mathrm{F}+\mathrm{A}$ group. When mice were immunized with FMDV formulated with alum and poly $(\mathrm{I}: \mathrm{C})$, the obtained antibody titers were higher and almost equivalent to that in the $\mathrm{F}+\mathrm{A}$ group. However, immunization to FMDV formulated with alum, R848, and poly(I:C) induced a striking, fourfold higher antibody, even higher than that in the $\mathrm{F}+206$ group at 14 and $21 \mathrm{dpv}(p<0.05)$. All above results showed that the combination of R848 and poly(I:C) played an important role in boosting anti-FMDV antibodies.

\section{Stimulation of immunized mice splenocytes in vitro} $\mathrm{R} 848$ and poly(I:C) as adjuvant reportedly induce a substantial increase in both Th1- and Th2-type immune responses
$[19,20]$. To determine the potential functions of R848 and poly(I:C) accompanied with FMDV antigens in Th1/Th2type immune response, cytokine levels were assayed. As shown in Figure 3, R848 and poly(I:C) promoted IFN- $\gamma$ production. In the $\mathrm{F}+\mathrm{A}+\mathrm{R}+\mathrm{P}$ group, the level of IFN- $\gamma$ was fivefold higher than that in the F + A group and a little lower than that in the $\mathrm{F}+206$ group $(p>0.05)$. However, no significant difference was observed in IL-4 production between the $\mathrm{F}+\mathrm{A}+\mathrm{R}+\mathrm{P}$ and $\mathrm{F}+206$ groups $(p>0.05)$, indicating that $\mathrm{R} 848$ and poly $(\mathrm{I}: \mathrm{C})$ biased the immune response toward a Th1-type direction.

\section{Flow cytometry analysis}

To characterize the cell-mediated immune responses, BALB/C mice were sacrificed and a single splenocyte suspension was prepared at $21 \mathrm{dpv}$. The $\mathrm{T}$ cell antigen receptor-CD3 complex plays an important role in the recognition and response to antigens. CD4 and CD8 are $\mathrm{T}$ cell surface glycoproteins that recognize major histocompatibility complex (MHC) antigens and play a critical role in signal transduction and $\mathrm{T}$ cell activation [21]. When $\mathrm{CD}^{+} \mathrm{CD}^{+}$cells were evaluated post-vaccination, the $\mathrm{F}+\mathrm{A}$ group remained unchanged relative to the PBS group, and the other groups had higher percentages of this cells than the PBS group. However, no significant difference was observed between the $\mathrm{F}+206$ and $\mathrm{F}+\mathrm{A}+\mathrm{P}+\mathrm{R}$ groups $(p>0.05)$ (Figure 4a). The percentage of $\mathrm{CD}^{+} \mathrm{CD}^{+} \mathrm{T}$ cells was also evaluated, except for the $\mathrm{F}+\mathrm{A}$ group, relative to the PBS group. However, when using the same specific antigens, the ability to stimulate CD8 T cell proliferation through different immune formulation was better in the $\mathrm{F}+\mathrm{A}+\mathrm{R}, \mathrm{F}+\mathrm{A}+\mathrm{P}$, and especially in the $\mathrm{F}+\mathrm{A}+\mathrm{R}+\mathrm{P}$ groups (Figure $4 \mathrm{~b}$ ).

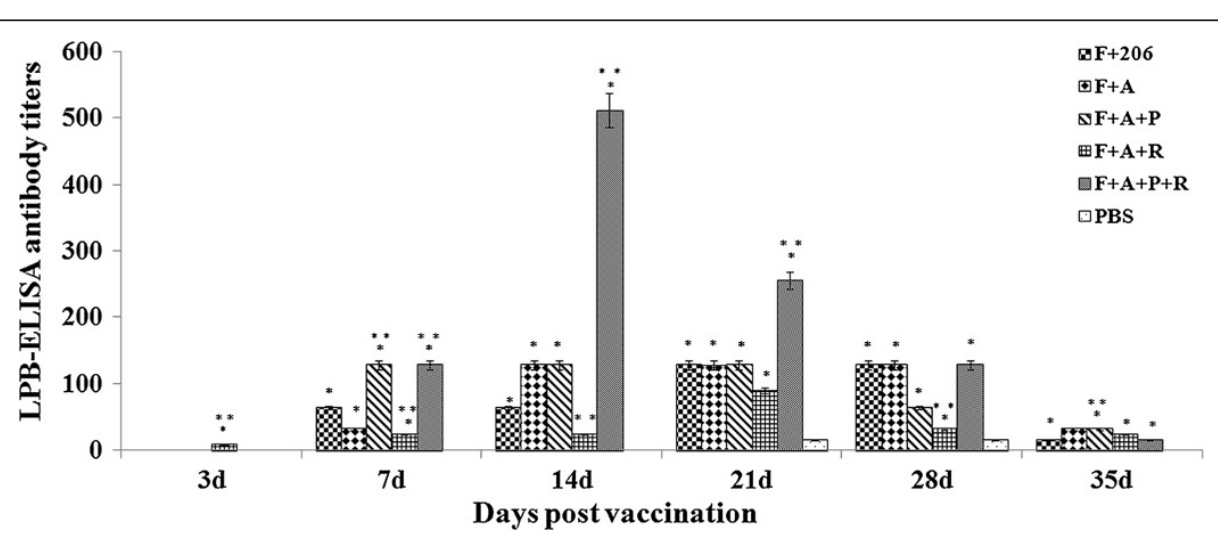

Figure 2 Enhancement of anti-FMDV IgG antibody by the immunization of FMDV antigens together with R848 and poly(l:C). Mice were bled at different dpv's. Sera from three mice were pooled together within the same group, and total IgG anti-FMDV antibody titers were detected using ELISA. One asterisk indicates that $p<0.05$ when comparing results from the ISA206, $F+A, F+A+P, F+A+R$, or $F+A+P+R$ groups to the PBS group. Two asterisks indicate $p<0.05$ when comparing results from the ISA206, $F+A+P, F+A+R$, or $F+A+P+R$ groups with the $F+A$ group. Each bar represents the mean antibody titer \pm standard error of 12 mice per group. 

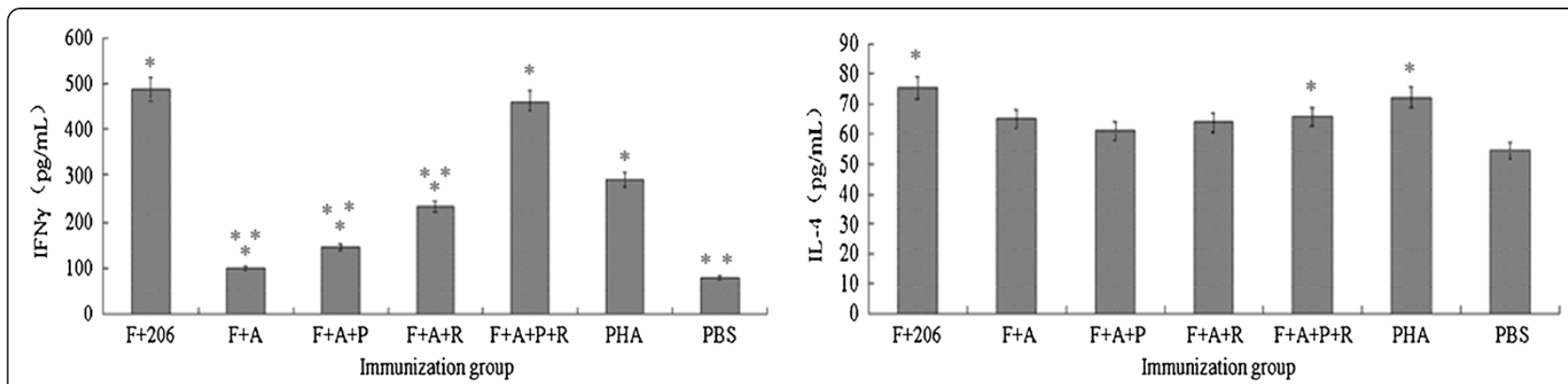

Figure 3 Induction of IFN- $\gamma$ and IL-4 by the immunized mice splenocytes. Mice were sacrificed at $35 \mathrm{dpv}$. Spleens were isolated and ground into single cells under sterile conditions. Single spleen lymphocyte suspensions $\left(5 \times 10^{6} / \mathrm{ml}\right)$ were obtained using commercial EZ-SepTM Mouse 1× Lymphocyte Separation Medium. About $200 \mu \mathrm{l}$ of cells was stimulated by FMDV antigens as specific antigen, PHA as positive control, and PBS as negative control . One asterisk indicates that $p<0.05$ when comparing results from the ISA206, $F+A, F+A+P, F+A+R, F+A+P+R$, or $P H A$ groups to the PBS group. Two asterisks indicate $p<0.05$ when comparing results from the $F+A, F+A+P, F+A+R$, or $F+A+P+R$ to ISA206 groups. Data are shown as the mean \pm standard error of 12 mice per group.

\section{Discussion}

The important finding of this study was that R848, poly $(\mathrm{I}: \mathrm{C})$, and $\mathrm{Al}(\mathrm{OH})_{3}$ enhanced the immune response against the FMDV, which has not yet been reported. The immunization of FMDV formulated with R848, poly $(\mathrm{I}: \mathrm{C})$, and $\mathrm{Al}(\mathrm{OH})_{3}$ markedly augmented antibody and cellular immune responses. However, weak humoral and cellular responses were elicited by FMDV and $\mathrm{Al}(\mathrm{OH})_{3}$ immune formulation.

The immunomodulatory effects of imidazoquinolines have been extensively studied both in mice and humans. Imiquimod, the first synthetic imidazoquinoline, is approved by the FDA for the topical treatment of viruses, such as human papillomavirus and genital HSV-2. R848, another imidazoquinoline, has been shown to preferentially enhance Th1 immune response through the recognition of TLR7 in antigen-presenting cells in mice, especially DCs [22]. Their binding induced the activation of DCs and the production of Th1-biased cytokines, such as TNF- $\alpha$, IL-12, and IFN- $\gamma$. Immune response against FMDV in natural hosts is probably T-cell dependent, and cell-mediated immunity may be involved in the clearance of persistent FMDV [23]. Ideally, a FMDV vaccine should be able to prime Th1/Th2-balanced immune responses to eliminate FMDV infection. The Th1 cytokines induced in vaccinated animals were correlated with the ability to control viral replication. The expression of IL-12 and IFN- $\gamma$ in immune cells responding to the FMDV reflects a dominance of Th1 type cells that can contribute to virus clearance. In general, Th1 cells are better endowed than Th2 to deal with viral infections [24].

Poly(I:C) could increase Th1 cytokines and type I IFNs by activating innate immunity through TLR3 and some other molecules mediating signal transduction. Then, DC maturation and B cell activation are induced [25]. Potent $\mathrm{CD}^{+}{ }^{+} \mathrm{T}$ cell and humoral immune responses can thus be induced. Moreover, both R848 and poly(I:C) could generate $\mathrm{CD}^{+} \mathrm{T}$ cell immune response through different mechanisms [26,27]. Collectively, these data
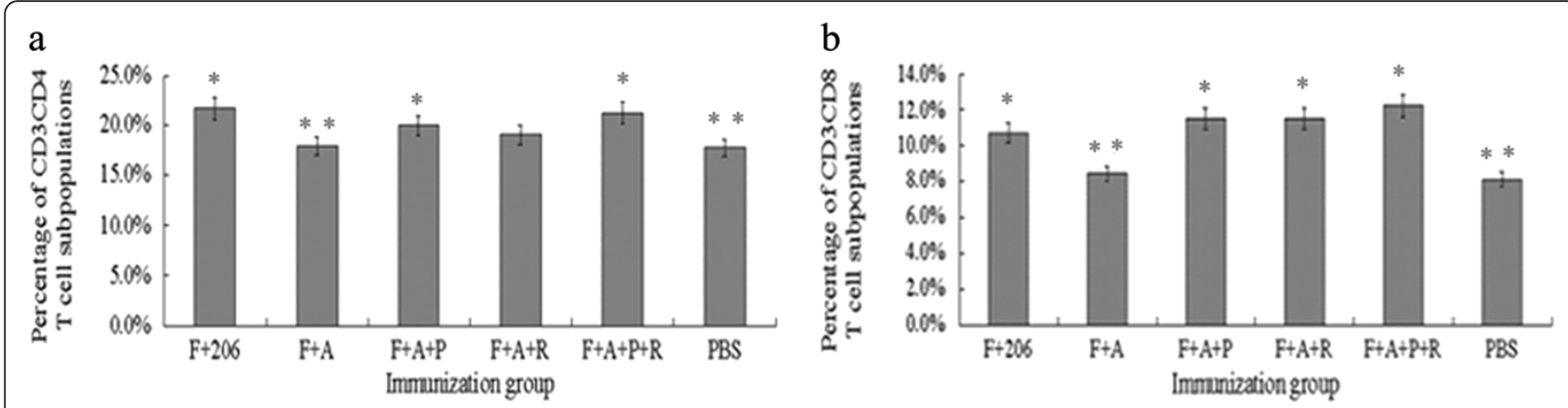

Figure 4 Effect induced by FMDV with different chemicals on T lymphocyte subsets of mouse spleen. The proportions of $C D 3^{+} C D 4^{+}$and $\mathrm{CD}^{+} \mathrm{CD}^{+}$subsets were assessed by two-color flow cytometry analysis. (a) $\mathrm{CD} 3^{+} \mathrm{CD} 4^{+} T$ cells from immunized mouse spleen. (b) $C D 3^{+} \mathrm{CD} 8{ }^{+} \mathrm{T}$ cells from immunized mouse spleen. One asterisk indicates that $p<0.05$ when comparing results from the ISA206, $F+A, F+A+P, F+A+R, F+$ $A+P+R$, or PHA groups to the PBS group. Two asterisks indicate $p<0.05$ when comparing results from the $F+A, F+A+P, F+A+R$, or $F+A+$ $P+R$ groups to the ISA206 group. All experiments were obtained in triplicate, and data shown are the mean \pm standard error. Representatives from three independent experiments are shown. 
strongly support the ability of R848 and poly(I:C) as immunomodulators for improving humoral and cellular immune responses.

Pure FMDV protein antigens have poor immunogenicity, which is the main cause of low immune efficacy in FMDV control and prevention. Using adjuvants can improve immunotherapy or vaccines. However, adjuvants used in FMD vaccines are salts of aluminum and mineral oil. Salts of aluminum have good safety record but produce poor $\mathrm{T}$ cell responses, and mineral oil produces high Th1 cell response but causes severe local toxicity. As part of the present study, the co-delivery of these materials accompanying FMDV must not induce severe local and general toxicity. Fortunately, observations of mice body weight, diurnal thermal variation of body temperature, animal behaviors, and pathological changes at the injection sites revealed that these materials were completely safe for use (data not shown).

Adjuvants such as alum or ISA206 alone can promote strong antibody responses. However, when added with R848 and poly(I:C), the antibody titers induced by FMDV were even higher than that in the $\mathrm{F}+\mathrm{A}$ or $\mathrm{F}+$ 206 groups at $14 \mathrm{dpv}$, which indicated that R848 and poly(I:C) may be important for humoral response regulation.

In vitro analyses of the effects of $\mathrm{R} 848$ and poly(I:C) on immune cells showed that they induced the up-regulation of IFN- $\gamma$ production and down-regulation of IL-4, which meant that $\mathrm{R} 848$ and poly(I:C) shifted the immune responses caused by FMDV and $\mathrm{Al}(\mathrm{OH})_{3}$ toward a Th1 direction. In vivo, R848 and poly(I:C) markedly affected the subpopulation of $\mathrm{T}$ lymphocyte cells, which enhanced both the percentages of $\mathrm{CD}_{4}^{+}$and $\mathrm{CD}^{+} \mathrm{T}$ cells when the two TLR agonists were administered together. Therefore, the two immunoregulatory materials could work together to improve the cellular responses induced by FMDV antigens formulated with alum.

\section{Conclusions}

The study provided substantial evidence of the use of R848 and poly(I:C) as TRL agonists for FMDV alum vaccines in a mice model. Particular application was demonstrated for inducing a high amount of IgG antibody and Th1-biased immune responses. The findings can serve as a foundation for further studies on these TLR agonists for FMDV protein vaccination in large animals.

\section{Competing interests}

The authors declare that they have no competing interests.

\section{Authors' contributions}

$\mathrm{DL}$ and $\mathrm{ZL}$ : conceived and designed the study. CZ, SQ, ZL, PS, YC, YC, HB, YF, $P L, X B$, and $B X$ performed the data collection. $C Z$ wrote the first draft of the paper, and DL critically revised the manuscript for writing errors and important intellectual content. ZL is the guarantor. All authors approved the final version of the manuscript to be published.

\section{Acknowledgements}

We thank Mrs. Shun-Yun Qi for her assistance in the detection of T lymphocyte subsets by flow cytometry. This work was supported by grants from the Special Program for Major Science and Technology of Gansu Province, China (Grant No. 1102NKDA032) and the Natural Science Foundation of Gansu Province, China (Grant No. 3ZS061-A25-070).

Received: 30 May 2013 Accepted: 31 December 2013

Published: 3 January 2014

\section{References}

1. Gerner W, Denyer MS, Takamatsu HH, Wileman TE, Wiesmüller KH, Pfaff E, Saalmüller A: Identification of novel foot-and-mouth disease virus specific T-cell epitopes in c/c and d/d haplotype miniature swine. Virus Res 2006, 121:223-228.

2. Sobrino F, Saiz M, Jimenez-Clavero MA, Nunez Jl, Rosas MF, Baranowski E, Ley V: Foot-and-mouth disease virus: a long known virus, but a current threat. Vet Res 2001, 32:1-30.

3. Dunn CS, Donaldson Al: Natural adaption to swine of a Taiwanese isolate of foot-and-mouth disease virus. Vet Rec 1997, 141:174-175.

4. Donaldson Al, Alexandersen $\mathrm{S}$, Sorensen $\mathrm{JH}$, Mikkelsen T: Relative risks of the uncontrollable (airborne) spread of FMD by different species. Vet Rec 2001, 148:602-604.

5. Patil PK, Bayry J, Ramakrishna C, Hugar B, Misra LD, Natarajana C: Immune responses of goats against foot-and-mouth disease quadrivalent vaccine: comparison of double oil emulsion and aluminiumhydroxide gel vaccines in eliciting immunity. Vaccine 2002, 20:2781-2789.

6. Aucouturier J, Dupuis L, Ganne V: Adjuvants designed for veterinary and human vaccines. Vaccine 2001, 19:2666-2672.

7. Gay NJ, Gangloff M: Structure and function of toll receptors and their Ligands. Annu Rev Biochem 2007, 76:141-165.

8. Geller MA, Cooley S, Argenta PA, Downs LS, Carson LF, Judson PL, Ghebre R, Weigel B, Panoskaltsis-Mortari A, Curtsinger J, Miller JS: Toll-like receptor-7 agonist administered subcutaneously in a prolonged dosing schedule in heavily pretreated recurrent breast, ovarian and cervix cancers. Cancer Immunol Immunother 2010, 59:1877-1884.

9. Noreen M, Shah MAA, Mall SM, Choudhary S, Hussain T, Ahmed I, Jalil SF, Raza MI: TLR4 polymorphisms and disease susceptibility. Inflamm Res 2012, 61:177-188.

10. Heil F, Hemmi H, Hochrein H, Ampenberger F, Kirschning C, Akira S, Lipford $G$, Wagner H, Bauer S: Species-specific recognition of single-stranded RNA via toll- like receptor 7 and 8. Science 2004, 303:1526-1529.

11. Drobits B, Holcmann M, Amberg N, Swiecki M, Grundtner R, Hammer M, Colonna M, Sibilia M: Imiquimod clears tumors in mice independent of adaptive immunity by converting pDCs into tumor-killing effector cells. J Clin Invest 2012, 122:575-585.

12. Torii $Y$, Ito $T$, Amakawa $R$, Sugimoto $H$, Amuro $H$, Tanijiri T, Katashiba $Y$, Ogata M, Yokoi T, Fukuhara S: Imidazoquinoline acts as immune adjuvant for functional alteration of thymic stromal allergic $T$ cell response. J Immunol 2008, 181:5340-5349.

13. Van LP, Bardel E, Gregoire S, Vanoirbeek J, Schneider E, Thieblemont N Treatment with the TLR7 agonist R848 induces regulatory T-cellmediated suppression of established asthma symptoms. Eur J Immunol 2011, 41:1992-1999.

14. Smirnov D, Schmidt JJ, Capecchi JT, Wightman PD: Vaccine adjuvant activity of 3 M-052: an imidazoquinoline designed for local activity without systemic cytokine induction. Vaccine 2011, 29:5434-5442.

15. Johnston D, Zaidi B, Bystryn JC: TLR7 imidazoquinoline ligand 3 M-019 is a potent adjuvant for pure protein prototype vaccines. Cancer Immunol Immunother 2007, 56:1133-1141.

16. Tomai MA, Vasilakos JP: TLR-7 and-8 agonists as vaccine adjuvants. Exp Rev Vaccines 2011, 10:405-407.

17. Yang M, Clavijo A, Suarez-Banmann R, Avalo R: Production and characterization of two serotype independent monoclonal antibodies against foot- and-mouth disease virus. Vet Immunol Immunopathol 2007, 115:126-134.

18. Kim CH, Chan DP, Lee AY: Administration of poly (I: C) improved dermatophagoides farinae-induced atopic dermatitis-like skin lesions in NC/Nga mice by the regulation of Th1/Th2 balance. Vaccine 2012, 30:2405-2410. 
19. Weeratna RD, Makinen SR, McCluskie MJ, Davis HL: TLR agonists as vaccine adjuvants: comparison of CpG ODN and Resiquimod (R-848). Vaccine 2005, 23:5263-5270.

20. Ichinohe T, Watanabe I, Ito S, Fujii H, Moriyama M, Tamura S, Takahashi H, Sawa H, Chiba J, Kurata T, Sata T, Hasegawa H: Synthetic double-stranded RNA Poly(l: C) combined with mucosal vaccine protects against influenza virus infection. J Virol 2005, 79:2910-2919.

21. Marathias K, Pinto C, Rodberg G, Preffer F, Wong J, Kradin R: The T cell antigen receptor $\mathrm{CD} 3: \mathrm{CD} 4$ molecular complex is diminished on the surface of pulmonary lymphocytes. Am J Pathol 1994, 145:1219-1227.

22. Baenziger S, Heikenwalder M, Johansen P, Schlaepfer E, Hofer U, Miller RC, Diemand S, Honda K, Kundig TM, Aguzzi A, Speck RF: Triggering TLR7 in mice induces immune activation and lymphoid system disruption resembling HIV-mediated pathology. Blood 2009, 113:377-388

23. Batista A, Quattrocchi V, Olivera V, Langellotti C, Pappalardo JS, Di Giacomo S, Mongini C, Portuondo D, Zamorano P: Adjuvant effect of Cliptox on the protective immune response induced by an inactivated vaccine against foot and mouth disease virus in mice. Vaccine 2010, 28:6361-6366.

24. Ma M, Jin N, Shen G, Zhu G, Liu HJ, Zheng M, Lu H, Huo X, Jin M, Yin G, $\mathrm{Ma} \mathrm{H}$, Li X, Ji Y, Jin K: Immune responses of swine inoculated with a recombinant fowlpox virus co-expressing P12A and $3 \mathrm{C}$ of FMDV and swine IL-18. Vet Immunol Immunopathol 2008, 121:1-7.

25. Tewari K, Flynn BJ, Boscardin SB, Kastenmueller K, Salazar AM, Anderson CA, Soundarapandian V, Ahumada A, Keler T, Hoffman SL, Nusenzweig MC, Sreinman RM, Seder RA: Poly(l:C) is an effective adjuvant for antibody and multi-functional CD4 + T cell responses to Plasmodium falciparum circumsporozoite protein (CSP) and a DEC-CSP in non human primates. Vaccine 2010, 28:7256-7266.

26. Pufnock JS, Cigar M, Rolczynski LS, Andersen-Nissen E, Wolfl M, McElrath MJ, Greenberg PD: Priming CD8+ T cells with dendritic cells matured using TLR4 and TLR7/8 ligands together enhance generation of CD8 + T cells retaining CD28. Blood 2011, 117:6542-6551.

27. Wick DA, Martin SD, Nelson BH, Webb JR: Profound $C D 8^{+} T$ cell immunity elicited by sequential daily immunization with exogenous antigen plus the TLR3 agonist poly(l:C). Vaccine 2011, 29:984-993.

doi:10.1186/1746-6148-10-2

Cite this article as: Zhou et al.: Resiquimod and polyinosinic-

polycytidylic acid formulation with aluminum hydroxide as an adjuvant for foot-and-mouth disease vaccine. BMC Veterinary Research 2014 10:2.

\section{Submit your next manuscript to BioMed Central and take full advantage of:}

- Convenient online submission

- Thorough peer review

- No space constraints or color figure charges

- Immediate publication on acceptance

- Inclusion in PubMed, CAS, Scopus and Google Scholar

- Research which is freely available for redistribution 